\title{
Nitrogen Source Influences the Effect of Plant Growth-Promoting Rhizobacteria (PGPR) on Macadamia integrifolia
}

\author{
Marta Gallart 1,*D, Chanyarat Paungfoo-Lonhienne ${ }^{2}$, Axayacatl Gonzalez ${ }^{3}$ and Stephen J. Trueman 1 \\ 1 Environmental Futures Research Institute, Griffith University, Nathan, QLD 4111, Australia; \\ s.trueman@griffith.edu.au \\ 2 School of Agriculture and Food Sciences, The University of Queensland, St. Lucia, QLD 4072, Australia; \\ c.paungfoolonhienne@uq.edu.au \\ 3 Australian Institute for Bioengineering and Nanotechnology, The University of Queensland, \\ St. Lucia, QLD 4072, Australia; r.gonzalezgarcia@uq.edu.au \\ * Correspondence: marta.gallart.diumenge@gmail.com
}

Citation: Gallart, M.; Paungfoo-

Lonhienne, C.; Gonzalez, A.;

Trueman, S.J. Nitrogen Source

Influences the Effect of Plant

Growth-Promoting Rhizobacteria (PGPR) on Macadamia integrifolia.

Agronomy 2021, 11, 1064. https://

doi.org/10.3390/agronomy11061064

Academic Editors: José M. De la Rosa and Marina Paneque

Received: 15 March 2021

Accepted: 21 May 2021

Published: 25 May 2021

Publisher's Note: MDPI stays neutral with regard to jurisdictional claims in published maps and institutional affiliations.

Copyright: (c) 2021 by the authors. Licensee MDPI, Basel, Switzerland. This article is an open access article distributed under the terms and conditions of the Creative Commons Attribution (CC BY) license (https:// creativecommons.org/licenses/by/ $4.0 /)$
Abstract: The potential of plant growth-promoting rhizobacteria (PGPR) to improve plant growth and nutrient acquisition has received increased attention. This study investigated the synergistic effects of combining PGPR Paraburkholderia sp. SOS3 with the addition of inorganic N fertilizer (iN) or a combined application of inorganic $\mathrm{N}$ with organic manure-based fertilizer (iNoN) at low and high levels of $\mathrm{N}$ fertilization on Macadamia integrifolia seedling growth. We studied plant growth, mineral $\mathrm{N}$ in soil-leachate, and media physicochemical and microbial characteristics. Growth of seedlings fertilized with iNoN at high $\mathrm{N}$ level (iNoN 100) was enhanced by PGPR inoculation, with an increase of $32 \%$ in total biomass and $43 \%$ in $\mathrm{N}$ uptake, compared with uninoculated seedlings. No significant PGPR effect was observed on growth under low or high inorganic $\mathrm{N}$ treatments but PGPR significantly reduced $\mathrm{N}$ leaching after 3 weeks of fertilization. We found a positive relationship between media and plant $\delta^{15} \mathrm{~N}$ and plant $\mathrm{N}$ uptake, and a strong increase in microbial-biomass $\mathrm{N}$ under the most productive fertilization treatment (iNoN 100 with PGPR), compared with the other $\mathrm{N}$ treatments (without or with PGPR). The results suggest that PGPR improves $\mathrm{N}$ acquisition by reducing mineral $\mathrm{N}$ loss and increasing plant $\mathrm{N}$ availability, but that these effects depend on the $\mathrm{N}$ form and $\mathrm{N}$ level.

Keywords: Macadamia integrifolia; nitrogen source; organic fertilizer; Paraburkholderia; PGPR; biofertilizer

\section{Introduction}

Human alteration of the global nitrogen $(\mathrm{N})$ cycle is one of the most important drivers of global climate change [1]. This perturbation is driven predominantly by the increased production and use of inorganic fertilizers to sustain intensive agriculture and crop production [2]. Plant uptake of fertilizer-N is a fundamental process in the global $\mathrm{N}$ cycle. Only $30-50 \%$ of $\mathrm{N}$ compounds added to crops in modern agricultural field systems can be taken up by plants and much of the remaining $\mathrm{N}$ is leached to groundwater, causing eutrophication, potent greenhouse gas emissions, acid rain, and detrimental effects on the ozone layer [3]. In nursery and greenhouse production, the combination of containerized plants, well-drained potting media and frequent irrigation accelerates nutrient leaching and runoff [4]. A new revolution in agricultural innovation is required to ensure efficient fertilizer use without harming the environment [5]. This paradigm shift toward sustainable agriculture is essential to support the growing global population through a changing climate.

The cornerstone goals of sustainable nutrient management in nursery and field operations are to improve $\mathrm{N}$ use efficiency and minimize $\mathrm{N}$ leaching, while improving soil quality. The addition of organic fertilizers (e.g., composts or manures) as an alternative to conventional fertilizers has attracted attention $[6,7]$. Organic fertilizers not only supply 
nutrients to plants, but also provide the organic matter that controls the soil biogeochemical cycles and ecological processes that improve soil health [8]. However, studies that address the preferences for, and partitioning of, $\mathrm{N}$ forms among plants provide varying results. This is partly because direct utilization of $\mathrm{N}$ derived from organic fertilizers is often variable due to $\mathrm{N}$ immobilization and the progressive release of organically bound $\mathrm{N}$ in soils over time $[9,10]$. Microbially-mediated processes control the balance between mineralization and immobilization of nitrogenous compounds [11] and determine how much of the $\mathrm{N}$ is plant-available (primarily in the form of $\mathrm{NH}_{4}{ }^{+}, \mathrm{NO}_{3}{ }^{-}$and free amino acids) or lost via volatilization or leaching. It is increasingly recognized that combining inorganic fertilizers and organic amendments (e.g., manure) has beneficial effects in plant growth and yield, likely due to increases in soil nutrient storage and microbial functional diversity [12-14]. Organic and inorganic $\mathrm{N}$ fertilizers have different long-term impacts on soil characteristics and nutrient dynamics, which lead to changes in rhizosphere microbial communities and plant-N availability [15]. Due to the $\mathrm{N}$ isotope fractionation and isotopic discrimination against ${ }^{15} \mathrm{~N}$ during biological $\mathrm{N}$ transformation processes, variations in soil and plant natural abundance of ${ }^{15} \mathrm{~N}$ (i.e., $\delta^{15} \mathrm{~N}$ ) and ${ }^{15} \mathrm{~N}$ pulse-chase labeling provide insights into the dynamics of $\mathrm{N}$ cycling processes $[16,17]$. Nevertheless, the dynamics of $\delta^{15} \mathrm{~N}$ after organic and inorganic $\mathrm{N}$ additions are still unclear because $\delta^{15} \mathrm{~N}$ varies across spatial and temporal scales [18].

Complex crosstalk exists between plant roots and rhizosphere microorganism communities, which can impact plant development and health $[19,20]$. Plants roots and their associated microbiomes are influenced by biotic and abiotic factors [21], but plants can exert control over the composition of the root microbiome [22]. For instance, limited nutrient bioavailability can trigger the release of root exudates to harness microorganisms involved in nutrient acquisition [23]. Following this principle, significant research efforts have been made to isolate and inoculate plants with plant growth-promoting rhizobacteria (PGPR) (also referred as biofertilizers) as a direct strategy to stimulate crop growth. In addition to maximizing plant nutrient uptake, PGPR inoculation can increase biomass production [24], confer tolerance to abiotic stress [25], and induce resistance to pathogens [26]. Numerous PGPR-based formulations that contain free-living N-fixing bacteria, such as Azoarcus sp., Azospirillum sp., Azotobacter sp., Bacillus sp., Diazotrophicus sp., Gluconacetobacter sp., Herbaspirillum sp. and Paraburkholderia sp., have been developed commercially to reduce the input of inorganic fertilizers [27]. However, the use of PGPR is far from being a widespread agricultural practice; benefits range from none to large across crops, soils and climate conditions. This variability is attributed to several factors, mainly specificity in host interactions, but also to the formulation and inoculation technologies that determine shelf-life and effectiveness under field conditions [28]. The co-application of PGPR and carrier substrates has become an effective strategy to establish microbial inoculants in the rhizosphere. For instance, the use of organic amendments as carriers (e.g., manures) promotes early rhizosphere and root microbial colonization, due to the role of organic matter in enhancing microbial growth [29,30].

The development of synergistic fertilizer formulations that combine highly effective rhizobacteria with different $\mathrm{N}$ forms has far-reaching consequences for the efficiency of agricultural crop production and the remediation of soil health. Recently, Paungfoo-Lonhienne et al. [31,32] reported that PGPR added to a combined organic and inorganic $\mathrm{N}$-fertilizer enhanced the growth and reduced $\mathrm{N}$ leaching of kikuyu grass (Pennisetum clandestinum) and sugar cane (Saccharum officinarum $\times$ spontaneum). Here, we further assessed whether this combination of organic and inorganic N-fertilizer benefited macadamia (Macadamia integrifolia), a putatively non-mycorrhizal flowering plant. The study of PGPR SOS3 in Australian macadamias is relevant due to the fact that sugar cane and macadamia crops usually co-exist in the same geographical area and are subject to crop succession. We investigated the effects of PGPR on macadamia seedlings, grown under low and high $\mathrm{N}$ additions of inorganic $\mathrm{N}$ fertilizer (urea) or a combined application of inorganic $\mathrm{N}$ with poultry manurebased fertilizer, on plant growth, mineral $\mathrm{N}$ in soil-leachate $\left(\mathrm{NH}_{4}{ }^{+}-\mathrm{N}\right.$ and $\left.\mathrm{NO}_{3}{ }^{-}-\mathrm{N}\right)$, and 
media physicochemical and rhizosphere microbial characteristics. We hypothesized that inoculation with PGPR would promote growth in trees amended with combined inorganic and organic $\mathrm{N}$ forms, through a reduction in mineral $\mathrm{N}$ loss and an increase in plant $\mathrm{N}$ availability, but that these effects would depend on $\mathrm{N}$ level.

\section{Materials and Methods}

\subsection{Plant Material and Growing Conditions}

Seedlings of the industry-standard macadamia cultivar, 741, were used to study how macadamia responds to different $\mathrm{N}$ sources at low and high $\mathrm{N}$ levels, without or with the presence of PGPR. In February 2019, fresh macadamia cv. 741 seeds were placed individually about $3 \mathrm{~cm}$ deep into a $225 \mathrm{~mL}$ propagation tube filled with a fine seedraising mix. Seeds were oriented with the ventral suture facing horizontally to prevent the formation of crooked stems. Another $2 \mathrm{~cm}$ of potting mix was added to cover the seeds. Irrigation was provided by misting for $10 \mathrm{~min}$ three times a day for 12 weeks. Over 95\% germination was achieved. The seedlings were transplanted individually in May 2019 into $4.5 \mathrm{~L}$ pots containing $\mathrm{N}$-free industry-standard macadamia potting mix comprised of composted pine bark, coir pith and sand (Rocky Point Pty Ltd., Woongoolba, Australia) in addition to the $\mathrm{N}$-fertilizer treatments. The average $( \pm \mathrm{SE})$ biomass of seedlings before planting $(\mathrm{n}=5)$ was $1.78 \mathrm{~g} \pm 0.19 \mathrm{~g}$ dry mass $(\mathrm{DM})(0.91 \pm 0.14 \mathrm{~g}$ leaf $\mathrm{DM}, 0.47 \pm 0.08 \mathrm{~g}$ stem DM and $0.41 \pm 0.04 \mathrm{~g}$ root DM). Their average elemental composition $(\mathrm{n}=5)$ was $45.3 \pm 0.3 \%$ C, $1.0 \pm 0.1 \% \mathrm{~N}, 0.18 \pm 0.02 \% \mathrm{P}, 0.50 \pm 0.03 \% \mathrm{~K}, 29.7 \pm 8.0 \mathrm{mg} \mathrm{Al} \mathrm{kg}{ }^{-1}$, $6.6 \pm 0.3 \mathrm{mg} \mathrm{B} \mathrm{kg}^{-1}, 1.8 \pm 0.2 \mathrm{~g} \mathrm{Ca} \mathrm{kg}^{-1}, 8.5 \pm 1.3 \mathrm{mg} \mathrm{Cu} \mathrm{kg}^{-1}, 55.4 \pm 10.3 \mathrm{mg} \mathrm{Fe} \mathrm{kg}^{-1}$, $1.1 \pm 0.1 \mathrm{~g} \mathrm{Mg} \mathrm{kg}^{-1}, 16.4 \pm 3.9 \mathrm{mg} \mathrm{Mn} \mathrm{kg}^{-1}, 0.6 \pm 0.1 \mathrm{~g} \mathrm{Na} \mathrm{kg}^{-1}, 1.2 \pm 0.1 \mathrm{~g} \mathrm{~S} \mathrm{~kg}^{-1}$, and $15.2 \pm 1.1 \mathrm{mg} \mathrm{Zn} \mathrm{kg}^{-1}$.

This study used a plant growth-promoting rhizobacteria, the SOS3 PGPR bacterium (Sustainable Organic Solutions Pty Ltd., Long Pocket, Australia; patent application number PCT/AU2016/050453), from the genus Paraburkholderia. PGPR was grown and prepared following Paungfoo-Lonhienne et al. [31], using zeolite as a bacterial carrier. Ten grams of PGPR-zeolite was applied in PGPR-inoculated treatment pots (Table 1), while no PGPR or zeolite was added to uninoculated treatment pots. Nitrogen was added as conventional urea (iN, $47.0 \% \mathrm{~N}$ ) or as an N-equimolar combination of urea and poultry manure-based organic fertilizer (oN, EcoNPK ${ }^{\mathrm{TM}}$, containing 4.0\% N, 1.6\% P, 1.9\% K with C:N 5.3:1) (Sustainable Organic Solutions Pty Ltd., Long Pocket, Australia). EcoNPK had at least $50 \%$ of $\mathrm{N}$ coming from poultry manure. Urea was used as an inorganic $\mathrm{N}$ form due to its widespread use as a fertilizer. Urea and EcoNPK were in solid form and were applied once to the potting mix before transferring plants. Three nitrogen rates of 0,3 or $6 \mathrm{~g} \mathrm{~N}$ pot $^{-1}$ were applied in the form of urea or the combination of urea and manure to 20 uninoculated plants and 20 PGPR-inoculated plants (Table 1), with a total of 180 plants included in the experiment. Control plants were transferred into pots that contained no $\mathrm{N}$ other than what was present in the potting mix. $\mathrm{Ca}\left(\mathrm{H}_{2} \mathrm{PO}_{4}\right)_{2} \cdot \mathrm{H}_{2} \mathrm{O}$ and $\mathrm{K}_{2} \mathrm{SO}_{4}$ were added at levels that equalized the concentrations of phosphorus and potassium across treatments to 1.8 and $4.5 \mathrm{~g} \mathrm{pot}^{-1}$, respectively, to minimize confounding effects on plant growth. Pots were supplied twice with a basal micronutrient solution containing $35 \mathrm{mg} \mathrm{MgSO} 4.7 \mathrm{H}_{2} \mathrm{O}, 18 \mathrm{mg}$ $\mathrm{FeSO}_{4} .7 \mathrm{H}_{2} \mathrm{O}, 6 \mathrm{mg} \mathrm{CuSO} 4.5 \mathrm{H}_{2} \mathrm{O}, 5 \mathrm{mg} \mathrm{ZnSO} 4.7 \mathrm{H}_{2} \mathrm{O}, 0.4 \mathrm{mg} \mathrm{Na} 2\left[\mathrm{~B}_{4} \mathrm{O}_{5}(\mathrm{OH})_{4}\right] \cdot 8 \mathrm{H}_{2} \mathrm{O}$ and $0.02 \mathrm{mg} \mathrm{Na} 2 \mathrm{MoO}_{4} \cdot 2 \mathrm{H}_{2} \mathrm{O}$. The high level of $\mathrm{N}$ supplied corresponded to the recommended $\mathrm{N}$ rate for optimal macadamia growth in nurseries.

The seedlings were grown for 28 weeks under natural light in a glasshouse, with added $30 \%$ shade cloth, at the University of the Sunshine Coast $\left(26^{\circ} 43^{\prime} \mathrm{S}, 153^{\circ} 3^{\prime} \mathrm{E}\right)$, Queensland, Australia. The temperature was programmed to not exceed $25^{\circ} \mathrm{C}$, although this provided average mean daily temperatures of $26.6^{\circ} \mathrm{C}$ in summer, $22.2^{\circ} \mathrm{C}$ in autumn, $18.1^{\circ} \mathrm{C}$ in winter and $22.5^{\circ} \mathrm{C}$ in spring. The pots were positioned within the glasshouse in a completely randomized design. Irrigation was provided by overhead sprinklers, with the irrigation adjusted seasonally to maintain potting media at $60 \%$ water holding capacity (WHC). The pots were saturated with water every 2 weeks. The 28 week duration of the experiment 
was based on the assumed minimum time required for seedlings to develop significant differences in growth- and development-responses to $\mathrm{N}$ treatments, as well as the time taken for macadamia seedlings to approach sufficient height for use as rootstocks.

Table 1. Treatment compositions used for the macadamia seedling experiment. Each experimental treatment was applied to 20 replicate plants.

\begin{tabular}{|c|c|c|c|c|c|}
\hline Treatment & $\begin{array}{c}\text { PGPR } \\
\text { Inoculation }\end{array}$ & $\begin{array}{c}\mathrm{N} \\
\text { Level }\end{array}$ & N Form & $\begin{array}{l}\text { N Content } \\
\left(\operatorname{g~pot}^{-1}\right)\end{array}$ & $\begin{array}{l}\text { PGPR (g } \\
\left.\operatorname{pot}^{-1}\right)\end{array}$ \\
\hline Control & - & Nil & Nil & 0 & - \\
\hline \multirow{2}{*}{ iN 50} & -PGPR & Low & $100 \%$ Urea & 3 & - \\
\hline & +PGPR & Low & $100 \%$ Urea & 3 & 10 \\
\hline \multirow{2}{*}{ iNoN 50} & -PGPR & Low & $50 \%$ Urea, 50\% EcoNPK ${ }^{\mathrm{TM}}$ & 3 & - \\
\hline & $+\mathrm{PGPR}$ & Low & $50 \%$ Urea, $50 \%$ EcoNPK ${ }^{\mathrm{TM}}$ & 3 & 10 \\
\hline \multirow{2}{*}{ iN 100} & $-P G P R$ & High & $100 \%$ Urea & 6 & - \\
\hline & +PGPR & High & $100 \%$ Urea & 6 & 10 \\
\hline \multirow{2}{*}{ iNoN 100} & -PGPR & High & $50 \%$ Urea, $50 \%$ EcoNPK ${ }^{\mathrm{TM}}$ & 6 & - \\
\hline & +PGPR & High & $50 \%$ Urea, $50 \%$ EcoNPK ${ }^{\mathrm{TM}}$ & 6 & 10 \\
\hline
\end{tabular}

\subsection{Processing of Plant and Media Samples}

All replicate plants were dissected carefully after 28 weeks into four samples: leaves, stems, fine roots and primary roots. Root systems were carefully removed from the potting media and then rinsed in running tap water until no trace of media particles was evident. The dry mass of each of the biomass fractions (leaves, stems, fine- and primary-roots) was determined after oven-drying the samples at $60{ }^{\circ} \mathrm{C}$ for $48 \mathrm{~h}$.

Potting media samples were collected after 28 weeks to determine media physicochemical properties, including media moisture, $\mathrm{EC}, \mathrm{pH}$, and $\mathrm{C}$ and $\mathrm{N}$ concentrations. Samples for media moisture, and $\mathrm{C}$ and $\mathrm{N}$ concentrations, were oven-dried at $40^{\circ} \mathrm{C}$ and $60{ }^{\circ} \mathrm{C}$, respectively for at least $48 \mathrm{~h}$, while samples for $\mathrm{pH}$ and $\mathrm{EC}$ were stored at $4{ }^{\circ} \mathrm{C}$ no longer than $24 \mathrm{~h}$.

Rhizosphere media samples were collected after 12 and 28 weeks from 3 to 4 different replicate plants to analyze PGPR copy numbers and microbial-biomass N. Rhizosphere media for $\delta^{15} \mathrm{~N}$ isotopic signature was only collected after 28 weeks of growth. For each individual tree, we collected approximately $15 \mathrm{~g}$ of rhizosphere media by pooling three cores $(10 \mathrm{~cm}$ depth and $1.5 \mathrm{~cm}$ diameter) taken $5 \mathrm{~cm}$ from the base of the tree. Rhizosphere media samples were obtained by carefully shaking root systems and manually removing any remaining roots from the loose media that was attached to roots. Samples were homogenized, sieved $(2 \mathrm{~mm})$ and stored at $-80{ }^{\circ} \mathrm{C}$ (PGPR copy number), kept at $4{ }^{\circ} \mathrm{C}$ (microbial-biomass $\mathrm{N}$ ), or oven-dried at $60^{\circ} \mathrm{C}$ for $48 \mathrm{~h}$ (isotopic analysis).

\subsection{Analysis of Plant Growth and Physiology}

The relative content of chlorophyll was measured, using an atLEAF chlorophyll meter, a leaf-clip non-invasive sensor (FT Green LLC, Wilmington, DE), before plants were harvested. This meter estimates relative chlorophyll content by measuring radiation absorbance at two wavelengths $(660 \mathrm{~nm}$ and $940 \mathrm{~nm})$. The sensor was placed over leaf mesophyll tissue and the optical density was measured at a photon flux density of 800-1200 $\mu \mathrm{mol} \mathrm{m} \mathrm{m}^{-2} \mathrm{~s}^{-1}$. Three measurements were taken across leaves of similar ages and averaged to provide a single estimate per plant.

Relative biomass partitioning (shoot and root mass fractions) was calculated for each tree by dividing each of the biomass fractions by the total tree biomass. The root to shoot ratio (R:S) was calculated as root dry mass (including fine and primary roots) divided by shoot dry mass, with shoot dry mass including both stem and leaf dry mass. The fine-root mass fraction was calculated by dividing the fine-root dry mass by the total-root dry mass. 


\subsection{Physicochemical Analysis of Leachates, Plant Material and Potting Media}

The mineral $\mathrm{N}$ composition of the leachates was analyzed after 3, 11 and 28 weeks to assess whether the $\mathrm{N}$ treatment and PGPR inoculation reduced $\mathrm{N}$ loss. Pots were filled to full water capacity and then leached with $150 \mathrm{~mL}$ of water. Leachates from four replicate trees were collected, immediately stored at $-20^{\circ} \mathrm{C}$, and analyzed within $4 \mathrm{~d}$ of collection. The leachates were analyzed for $\mathrm{NH}_{4}{ }^{+}-\mathrm{N}$ and $\mathrm{NO}_{3}{ }^{-}-\mathrm{N}$ contents $\left(\mathrm{mg} \mathrm{L}^{-1}\right)$, which were determined using the $2 \mathrm{M} \mathrm{KCl}$ extraction and colorimetric spectrometry method [33]. Mineral $\mathrm{N}$ concentration $\left(\mathrm{N}_{\min }, \mathrm{mg} \mathrm{L}^{-1}\right)$ was calculated combining the values of $\mathrm{NH}_{4}{ }^{+}-\mathrm{N}$ and $\mathrm{NO}_{3}{ }^{-}-\mathrm{N}$ contents at each time point.

Media moisture (\%) after 28 weeks was calculated as the percentage of water contained in samples before drying approximately $150 \mathrm{~g}$ of potting media at $40{ }^{\circ} \mathrm{C}$ for at least $48 \mathrm{~h}$. $\mathrm{EC}$ and $\mathrm{pH}$ determination was performed by shaking 1:1 soil to water (w:v) extracts for 30 min before measuring EC and $\mathrm{pH}$, using calibrated electrodes at $25^{\circ} \mathrm{C}$ [34].

In order to determine $\mathrm{N}$ and $\mathrm{C}$ concentrations, subsamples of dry leaves, roots, and potting media from ten replicate trees were pulverized and analyzed by combustion, using a CHN analyzer (LECO, Saint Joseph, MI, USA). The concentrations of P and $\mathrm{K}$ in leaves from ten replicates were obtained by inductively coupled plasma-atomic emission spectroscopy [35] after nitric and perchloric acid digestion [36]. The plant $\mathrm{N}$ uptake (mg N plant ${ }^{-1}$ ) was calculated by multiplying the dry mass of leaf and roots by the corresponding $\mathrm{N}$ concentration. The leaf $\mathrm{P}$ uptake $\left(\mathrm{mg} \mathrm{P}\right.$ g dry mass leaf ${ }^{-1}$ ) and leaf $\mathrm{K}$ uptake (mg K g dry mass leaf ${ }^{-1}$ ) were calculated by multiplying the leaf dry mass by the corresponding $\mathrm{P}$ and $\mathrm{K}$ concentrations. $\mathrm{N}$ retained $\left(\mathrm{N}_{\mathrm{ret}}\right)$ in the medium was calculated by multiplying the $\mathrm{N}$ concentration in the medium by the estimated medium weight in each pot, assuming $50 \%$ water content.

\subsection{Isotopic Analysis}

The $\delta^{15} \mathrm{~N}$ isotope signature was analyzed in rhizosphere media and leaf samples from three replicate trees per treatment. Oven-dried rhizosphere media and leaf samples were homogenized to a fine powder and transferred to tin capsules. $\delta^{15} \mathrm{~N}$ natural abundance was obtained using an elemental analyzer (Sercon Europa EA-GSL, Sercon Ltd., Crewe, UK) coupled to a stable isotope ratio mass spectrometer (Sercon Hydra 20-22, Sercon Ltd., Crewe, UK).

\subsection{Genetic Identification of PGPR SOS3 Copies}

Copy numbers of the $16 \mathrm{~S}$ rRNA gene (16S copies mg media-1) and PGPR strain-specific gene PB_SOS3_004375 (PGPR copies mg media ${ }^{-1}$ ) were quantified after 12 and 28 weeks to study how treatments impacted the level of bacterial and PGPR rhizosphere colonization. After collection, rhizosphere samples were sieved $\left(2 \mathrm{~mm}\right.$ diameter) and stored immediately at $-80^{\circ} \mathrm{C}$. Rhizosphere DNA from three replicates per treatment was isolated in a double extraction from approximately $250 \mathrm{mg}$ of rhizosphere media, using the DNeasy PowerSoil kit (Qiagen, Hilden, Germany) following the manufacturer's protocol. The concentration of total extracted genomic DNA (gDNA) was determined using the Qubit dsDNA BR Quantification kit and a Qubit 2.0 Fluorometer (Invitrogen, Carlsbad, CA, USA). Copies of the bacterial ribosomal RNA (rRNA) gene were quantified by qPCR by amplifying the V3 and V4 regions ( $345 \mathrm{bp}$ fragment), using the primers $27 \mathrm{~F}$ forward $\left(5^{\prime}-\right.$ AGAGTTTGATCCTGGCTCAG-3') and 336R reverse (5'-ACTGCTGCSYCCCGTAGGAGTCT-3'). For PGPR, we used strain-specific primers that target the PB_SOS3_004375 gene (120 bp fragment): SOS3_4375_F forward (5'-CCGGACCGCTGAAATTCTAT-3') and SOS3_4375_R reverse (5'-ATCCACGGAATTCGCTCTTT-3'). Primers were designed using online tool PrimerQuest Tool (Integrated DNA Technologies, U.S.A.). Standard curves were prepared by recovering gDNA from PGPR. All samples were analyzed in triplicate with $10 \mu \mathrm{L}$ reactions containing $1 \times$ SsoAdvanced Universal SYBR Green Supermix (Bio-Rad Laboratories Inc., Hercules, CA, USA), $250 \mathrm{nM}$ of forward and reverse primers, and $10 \mathrm{ng}$ of microbial gDNA template. For both primer sets, the thermocycling program (C1000 Touch Thermal Cycler, Bio-Rad Laboratories Inc., Hercules, CA, USA) was carried out with an initial denatura- 
tion step of $98^{\circ} \mathrm{C}$ for $3 \mathrm{~min}$ followed by 40 cycles of denaturation at $95^{\circ} \mathrm{C}$ for $15 \mathrm{~s}$ and annealing/extension at $60^{\circ} \mathrm{C}$ for $30 \mathrm{~s}$ followed by a melting curve from 65 to $95^{\circ} \mathrm{C}$ with an increase of $0.5^{\circ} \mathrm{C}$ every $5 \mathrm{~s}$ following completion of thermocycling to verify the purity of the amplicons. The number of gene copies was divided by the exact amount of rhizosphere media used in the DNA extraction.

\subsection{Assessment of Microbial-Biomass $N$}

The microbial-biomass $\mathrm{N}$ of media rhizosphere samples after 12 weeks and 28 weeks (harvest) was analyzed, using a chloroform fumigation extraction method [37]. Briefly, two subsamples of fresh rhizosphere media were collected from each sample; the first $5 \mathrm{~g}$ subsample was fumigated with chloroform in a vacuumed chamber for $10 \mathrm{~d}$, while a duplicate $5 \mathrm{~g}$ subsample was treated as a control and stored at $4{ }^{\circ} \mathrm{C}$. Both subsamples were then extracted using $2 \mathrm{M} \mathrm{KCl}$, followed by a ninhydrin assay. Microbial-biomass $\mathrm{N}$ ( $\mathrm{mg} \mathrm{N} \mathrm{kg}^{-1}$ ) was calculated by multiplying the difference in ninhydrin-reactive nitrogen values of the fumigated and non-fumigated media samples with a correction factor of 3.1.

\subsection{Statistical Analysis}

The statistical analysis was performed using RStudio v. 1.2.5033 [38]. To test whether means for individual plant measures (dry mass, chlorophyll content, root parameters and nutrient uptake) differed among treatments, one-way analyses of variance (ANOVAs) were conducted, after confirming that the data met assumptions for normality and homogeneous variance. The data were tested for normality and homogeneity of variance using Shapiro-Wilk and Levene's tests, respectively. We used one-way ANOVAs due to the unbalanced design. Tukey's honestly significant difference (HSD) tests were performed when differences among treatment means were detected by ANOVA. The same approach was used to test for differences in treatment means for $\mathrm{N}_{\min }, \mathrm{NH}_{4}{ }^{+}-\mathrm{N}$ and $\mathrm{NO}_{3}{ }^{-}-\mathrm{N}_{\text {con- }}$ centrations in soil-leachate, potting media physicochemical properties, rhizosphere media and leaf $\delta^{15} \mathrm{~N}$ natural abundance, and microbial-biomass $\mathrm{N}$. Two-way analyses of variance were conducted to test whether means for copy numbers of $16 \mathrm{~S}$ rRNA gene and PGPR strain-specific gene differed among treatments or time points. When the treatment $\times$ time interaction was significant, the effects of time within each treatment and treatment within time were analyzed by one-way ANOVA. The relationships between plant $\mathrm{N}$ uptake and media $\delta^{15} \mathrm{~N}$, and plant $\mathrm{N}$ uptake and leaf $\delta^{15} \mathrm{~N}$ were assessed by Pearson's correlation analysis, using three replicates per treatment. Means are presented with standard errors, and differences were regarded as significant at $p<0.05$.

\section{Results}

\subsection{Tree Growth, Root Responses and Nutrient Status}

Macadamia total biomass was similar among low $\mathrm{N}$ treatments, while biomass production among high $\mathrm{N}$ treatments was higher in the combined inorganic and organic fertilizer than in inorganic $\mathrm{N}$ fertilizer alone (Table 2; Figure 1a,b). Macadamia growth increased with the increasing application rate of combined inorganic and organic fertilizer (iNoN 50, iNoN 100), though only when PGPR was added. No significant differences were found between $\mathrm{N}$ levels of the inorganic fertilizer treatments. Macadamia seedlings grown in substrate amended with the iNoN 100 treatment had 32\% higher total biomass (Table 2, Figure 1b), 27\% higher leaf dry mass (Figure 1b,c), 26\% higher stem dry mass (Figure 1b,d) and $60 \%$ higher fine-root dry mass (Figure 1e) when inoculated with PGPR than when they were uninoculated. The chlorophyll content in leaves at the end of the experiment was approximately 17\% higher in the iNoN 100 treatments than in the low and high inorganic $\mathrm{N}$ treatments (iN 50, iN 100), without or with PGPR inoculation (Table 2).

Significant differences in above- and below-ground biomass partitioning were only observed between $\mathrm{N}$ levels of the combined inorganic and organic fertilizer (iNoN 50, iNoN 100) when not inoculated with PGPR (Table 2). Uninoculated iNoN 100 trees had $14 \%$ higher shoot mass fraction and $22 \%$ lower root mass fraction than uninoculated iNoN 
50 trees. In contrast, inoculated iNoN 50 and iNoN 100 trees had similar aboveground mass fractions (Table 2). Differences in fine-root mass fraction ( $\mathrm{g} \mathrm{g} \mathrm{root}^{-1}$ ) were observed between uninoculated and inoculated trees growing under the combined inorganic and organic $\mathrm{N}$ fertilizer at high $\mathrm{N}$ level (iNoN 100), with the fine-root mass fraction increasing by $19 \%$ after PGPR inoculation (Table 2 ).

a

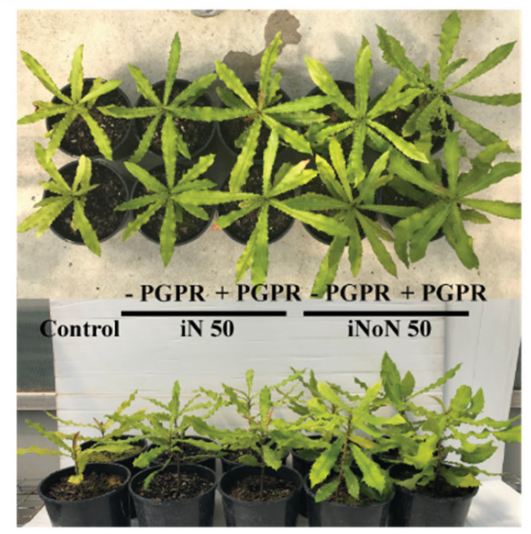

b

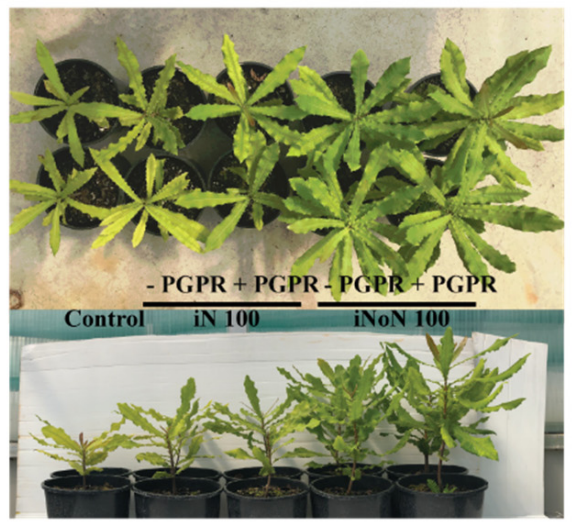

c

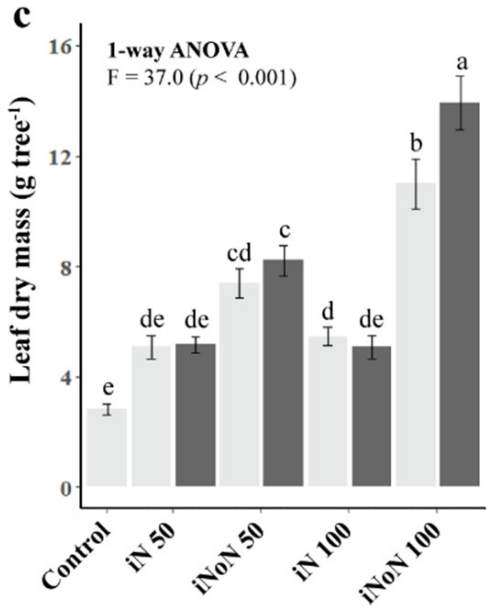

\section{d}

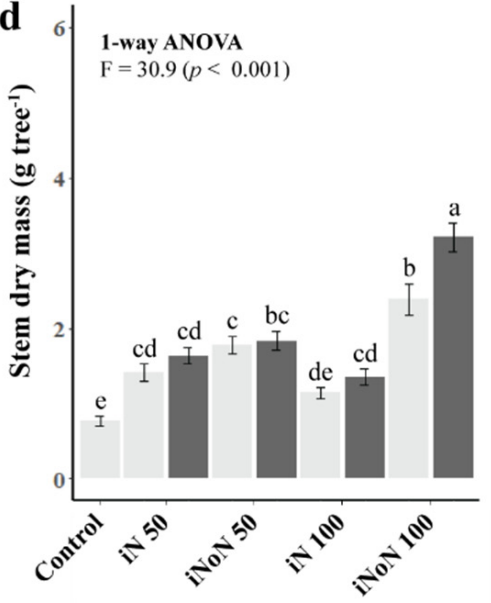

e

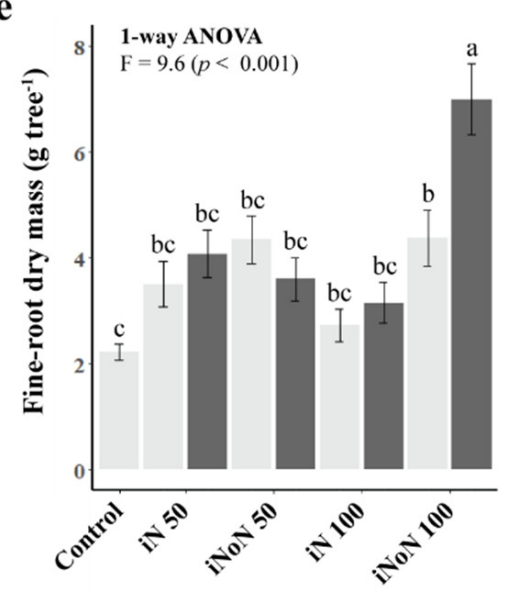

Figure 1. Effects of the plant growth-promoting rhizobacteria (PGPR) on macadamia cultivar 741 seedlings grown under (a) low $\mathrm{N}$ and (b) high $\mathrm{N}$ additions of inorganic $\mathrm{N}$ fertilizer (iN, 100\% urea) or a combined application of inorganic $\mathrm{N}$ with poultry manure (iNoN, 50\% urea $+50 \%$ EcoNPK ${ }^{\mathrm{TM}}$ ) after 28 weeks. Treatment effect on (c) leaf, (d) stem, (e) fine-root dry mass $\left(\mathrm{g}_{\text {tree }}{ }^{-1}\right.$ ). Control, no $\mathrm{N}$ applied other than that present in the potting mix. Light grey bars represent uninoculated treatments; dark grey bars display treatments inoculated with PGPR. Shown are mean absolute dry mass measures $( \pm$ SE, $\mathrm{n}=20$ ). Different letters above means indicate significant differences among treatments (one-way ANOVA and Tukey's post hoc tests, $p<0.05)$.

Plant N uptake in the iNoN 100 treatment with PGPR was 43\% higher than that without PGPR, approximately 100\% higher than iNoN 50 without or with PGPR, and approximately $190 \%$ higher than iN 50 and iN 100 without or with PGPR (Table 2). Leaf P uptake in the iNoN 100 treatment with PGPR was over 79\% greater than the iNoN 50 treatment without or with PGPR, and at least 188\% higher than iN 50 and iN 100 without or with PGPR. Leaf K uptake in the iNoN 100 treatment with PGPR was 43\% higher than that without PGPR, 102\% higher than iNoN 50 without or with PGPR, and over $225 \%$ higher than iN 50 and iN 100 without or with PGPR (Table 2).

\subsection{Mineral $N$ in Soil-Leachate}

The addition of PGPR to iN 100 reduced mineral N leaching after 3 weeks by $45 \%$ compared with uninoculated trees (Figure 2a), while mineral $\mathrm{N}$ leaching in the other $\mathrm{N}$ 
treatments was not influenced significantly by PGPR. The presence of PGPR reduced the $\mathrm{NO}_{3}{ }^{-}-\mathrm{N}$ concentration in iNoN 100 leachate after 3 weeks by $88 \%$ (Figure $2 \mathrm{~b}$ ). Leachate $\mathrm{NH}_{4}{ }^{+}-\mathrm{N}$ levels after 3 weeks were over two-fold higher growing under the iN 100 treatment without PGPR than in low $\mathrm{N}$ treatments without or with PGPR (iN 50, iNoN 50) (Figure 2c). Mineral $\mathrm{N}, \mathrm{NO}_{3}{ }^{-}-\mathrm{N}$ and $\mathrm{NH}_{4}{ }^{+}-\mathrm{N}$ levels decreased markedly by 11 weeks (Figure $2 \mathrm{~d}-\mathrm{f}$ ) at which stage they were not significantly different among treatments. The concentrations of mineral $\mathrm{N}$ forms were below the limit of detection $\left(<0.2 \mathrm{mg} \mathrm{L}^{-1}\right)$ at 28 weeks (data not presented).

Table 2. Total biomass, chlorophyll content, biomass partitioning, root traits and nutrient uptake of macadamia seedlings after 28 weeks growing under different fertilizer $\mathrm{N}$ sources (iN, iNoN) and PGPR inoculation (-PGPR, +PGPR).

\begin{tabular}{|c|c|c|c|c|c|c|c|c|c|c|}
\hline & \multirow{2}{*}{$\begin{array}{c}\text { Control } \\
-\end{array}$} & \multicolumn{2}{|c|}{ iN 50} & \multicolumn{2}{|c|}{ iNoN 50} & \multicolumn{2}{|c|}{ iN 100} & \multicolumn{2}{|c|}{ iNoN 100} & \multirow[t]{2}{*}{$\mathbf{F}(p)$} \\
\hline & & -PGPR & +PGPR & -PGPR & +PGPR & -PGPR & +PGPR & -PGPR & +PGPR & \\
\hline Total biomass ( g tree $^{-1}$ ) & $\begin{array}{c}7.7 \pm \\
0.4 \mathrm{~d}\end{array}$ & $\begin{array}{c}12.4 \pm \\
1.0 \mathrm{~cd}\end{array}$ & $\begin{array}{c}13.5 \pm \\
0.9 c\end{array}$ & $\begin{array}{c}16.4 \pm \\
0.9 \mathrm{bc}\end{array}$ & $\begin{array}{c}16.7 \pm \\
1.1 \mathrm{bc}\end{array}$ & $\begin{array}{c}11.6 \pm \\
0.7 \mathrm{~cd}\end{array}$ & $\begin{array}{c}11.8 \pm \\
0.9 \mathrm{~cd}\end{array}$ & $\begin{array}{c}21.2 \pm \\
1.7 \mathrm{~b}\end{array}$ & $\begin{array}{c}27.9 \pm \\
1.8 \mathrm{a}\end{array}$ & $\begin{array}{c}28.3 \\
(<0.001)\end{array}$ \\
\hline Chlorophyll & $\begin{array}{c}24.1 \pm \\
0.7 \mathrm{~d}\end{array}$ & $\begin{array}{c}27.6 \pm \\
0.6 \mathrm{c}\end{array}$ & $\begin{array}{c}27.8 \pm \\
0.8 \mathrm{c}\end{array}$ & $\begin{array}{l}30.0 \pm \\
0.9 \mathrm{abc}\end{array}$ & $\begin{array}{c}29.5 \pm \\
0.8 b c\end{array}$ & $\begin{array}{c}27.8 \pm \\
0.8 \mathrm{c}\end{array}$ & $\begin{array}{c}28.0 \pm \\
0.8 \mathrm{c}\end{array}$ & $\begin{array}{c}32.9 \pm \\
0.9 \mathrm{a}\end{array}$ & $\begin{array}{c}32.4 \pm \\
0.4 \mathrm{ab}\end{array}$ & $\begin{array}{c}13.2 \\
(<0.001)\end{array}$ \\
\hline Shoot mass fraction $(\%)$ & $\begin{array}{c}46.7 \pm \\
1.2 \mathrm{~d}\end{array}$ & $\begin{array}{c}53.0 \pm \\
1.6 \mathrm{~cd}\end{array}$ & $\begin{array}{c}51.6 \pm \\
1.4 \mathrm{~cd}\end{array}$ & $\begin{array}{c}55.9 \pm \\
2.0 \mathrm{bc}\end{array}$ & $\begin{array}{c}60.7 \pm \\
1.4 \mathrm{ab}\end{array}$ & $\begin{array}{l}57.1 \pm \\
1.6 \mathrm{abc}\end{array}$ & $\begin{array}{c}55.0 \pm \\
1.3 \mathrm{bc}\end{array}$ & $\begin{array}{c}63.8 \pm \\
1.5 \mathrm{a}\end{array}$ & $\begin{array}{c}61.2 \pm \\
1.4 \mathrm{ab}\end{array}$ & $\begin{array}{c}12.4 \\
(<0.001)\end{array}$ \\
\hline Root mass fraction (\%) & $\begin{array}{c}53.3 \pm \\
1.2 \mathrm{a}\end{array}$ & $\begin{array}{c}47.0 \pm \\
1.6 \mathrm{ab}\end{array}$ & $\begin{array}{c}48.4 \pm \\
1.4 \mathrm{ab}\end{array}$ & $\begin{array}{c}44.1 \pm \\
2.0 \mathrm{bc}\end{array}$ & $\begin{array}{c}39.3 \pm \\
1.4 \mathrm{~cd}\end{array}$ & $\begin{array}{l}42.9 \pm \\
1.6 b c d\end{array}$ & $\begin{array}{c}45.0 \pm \\
1.3 \mathrm{bc}\end{array}$ & $\begin{array}{c}36.2 \pm \\
1.5 \mathrm{~d}\end{array}$ & $\begin{array}{c}38.8 \pm \\
1.4 \mathrm{~cd}\end{array}$ & $\begin{array}{c}12.4 \\
(<0.001)\end{array}$ \\
\hline R:S & $\begin{array}{c}1.17 \pm \\
0.06 \mathrm{a}\end{array}$ & $\begin{array}{c}0.93 \pm \\
0.07 \mathrm{~b}\end{array}$ & $\begin{array}{l}0.97 \pm \\
0.06 \mathrm{ab}\end{array}$ & $\begin{array}{l}0.83 \pm \\
0.06 \mathrm{bc}\end{array}$ & $\begin{array}{l}0.67 \pm \\
0.04 \mathrm{~cd}\end{array}$ & $\begin{array}{c}0.78 \pm \\
0.05 \mathrm{bcd}\end{array}$ & $\begin{array}{l}0.84 \pm \\
0.04 b c\end{array}$ & $\begin{array}{c}0.58 \pm \\
0.04 \mathrm{~d}\end{array}$ & $\begin{array}{l}0.65 \pm \\
0.04 \mathrm{~cd}\end{array}$ & $\begin{array}{c}12.2 \\
(<0.001)\end{array}$ \\
\hline $\begin{array}{l}\text { Fine-root mass fraction ( } \mathrm{g} g \\
\left.\operatorname{root}^{-1}\right)\end{array}$ & $\begin{array}{l}0.54 \pm \\
0.02 \mathrm{ab}\end{array}$ & $\begin{array}{l}0.57 \pm \\
0.02 \mathrm{ab}\end{array}$ & $\begin{array}{l}0.59 \pm \\
0.02 \mathrm{ab}\end{array}$ & $\begin{array}{l}0.58 \pm \\
0.02 \mathrm{ab}\end{array}$ & $\begin{array}{c}0.53 \pm \\
0.02 b\end{array}$ & $\begin{array}{c}0.52 \pm \\
0.03 b\end{array}$ & $\begin{array}{l}0.56 \pm \\
0.02 \mathrm{ab}\end{array}$ & $\begin{array}{c}0.53 \pm \\
0.02 b\end{array}$ & $\begin{array}{c}0.63 \pm \\
0.02 \mathrm{a}\end{array}$ & $\begin{array}{c}2.8 \\
(0.007)\end{array}$ \\
\hline N uptake ${ }^{1}\left(\right.$ mg N plant $\left.{ }^{-1}\right)$ & $\begin{array}{l}36.4 \pm \\
2.2 \mathrm{~d}\end{array}$ & $\begin{array}{l}61.5 \pm \\
7.7 \mathrm{~cd}\end{array}$ & $\begin{array}{l}63.8 \pm \\
5.2 \mathrm{~cd}\end{array}$ & $\begin{array}{c}95.7 \pm \\
7.4 \mathrm{bc}\end{array}$ & $\begin{array}{l}95.1 \pm \\
8.3 \mathrm{bc}\end{array}$ & $\begin{array}{c}65.3 \pm \\
5.8 \mathrm{~cd}\end{array}$ & $\begin{array}{c}66.3 \pm \\
3.8 \mathrm{~cd}\end{array}$ & $\begin{array}{c}132.5 \pm \\
13.5 b\end{array}$ & $\begin{array}{c}190.2 \pm \\
13.5 \mathrm{a}\end{array}$ & $\begin{array}{c}31.2 \\
(<0.001)\end{array}$ \\
\hline $\begin{array}{c}\text { P uptake }^{2}\left(\mathrm{mg} \mathrm{P}_{\text {P g dry mass }}\right. \\
\left.\text { leaf }^{-1}\right)\end{array}$ & $\begin{array}{l}24.8 \pm \\
3.9 \mathrm{c}\end{array}$ & $\begin{array}{l}32.8 \pm \\
6.0 \mathrm{c}\end{array}$ & $\begin{array}{l}31.2 \pm \\
3.9 \mathrm{c}\end{array}$ & $\begin{array}{l}42.0 \pm \\
5.1 \mathrm{bc}\end{array}$ & $\begin{array}{c}52.5 \pm \\
5.0 \mathrm{bc}\end{array}$ & $\begin{array}{l}22.7 \pm \\
3.4 \mathrm{c}\end{array}$ & $\begin{array}{l}31.8 \pm \\
3.4 \mathrm{c}\end{array}$ & $\begin{array}{l}65.3 \pm \\
8.8 \mathrm{ab}\end{array}$ & $\begin{array}{l}94.8 \pm \\
14.2 \mathrm{a}\end{array}$ & $\begin{array}{c}11.7 \\
(<0.001)\end{array}$ \\
\hline $\begin{array}{c}\text { K uptake }^{3}\left(\text { mg K g dry mass }_{\left.\text {leaf }^{-1}\right)}\right. \\
\text { g d }\end{array}$ & $\begin{array}{c}39.5 \pm \\
5.4 \mathrm{~d}\end{array}$ & $\begin{array}{c}57.3 \pm \\
8 \mathrm{~cd}\end{array}$ & $\begin{array}{l}55.0 \pm \\
6.4 \mathrm{~cd}\end{array}$ & $\begin{array}{l}83.5 \pm \\
7.1 \mathrm{bcd}\end{array}$ & $\begin{array}{c}95.9 \pm \\
9 \mathrm{bc}\end{array}$ & $\begin{array}{c}52.3 \pm \\
5.7 \mathrm{~cd}\end{array}$ & $\begin{array}{l}60.1 \pm \\
5.8 \mathrm{~cd}\end{array}$ & $\begin{array}{c}127.3 \pm \\
13.8 \mathrm{~b}\end{array}$ & $\begin{array}{c}181.6 \pm \\
21.2 \mathrm{a}\end{array}$ & $\begin{array}{c}19.2 \\
(<0.001)\end{array}$ \\
\hline
\end{tabular}

Shown are mean $( \pm S E)$ values from 20 replicates per treatment, except for nutrient uptake which was obtained from 10 replicates per treatment. Different letters indicate significant differences among treatments (one-way ANOVA and Tukey's post hoc tests, $p<0.05$ ).

${ }^{1}$ Nitrogen $(\mathrm{N}),^{2}$ phosphorus $(\mathrm{P})$ and ${ }^{3}$ potassium $(\mathrm{K})$.

\subsection{Potting Media Physicochemical Properties}

The moisture, $\mathrm{pH}$ and $\mathrm{EC}$ of the potting media did not differ among treatments at the end of the experiment, i.e., after 28 weeks (Table S1). However, significant differences in media $\mathrm{C}: \mathrm{N}$ were found in treatments amended with the combined inorganic and organic fertilizer (iNoN 50, iNoN 100), with iNoN 50 having higher media C:N than iNoN 100 regardless of PGPR inoculation (Table S1). In addition, differences in $\mathrm{N}_{\text {ret }}$ were only observed between PGPR-inoculated iNoN 100 and uninoculated low N fertilizers (iN 50, iNoN 50), with no significant differences between $\mathrm{N}$ addition and $\mathrm{N}$-free control (Table S1).

\section{4. $\delta^{15} \mathrm{~N}$ Isotope Signatures}

Significant differences in isotopic composition $\left(\delta^{15} \mathrm{~N}\right)$ were found among rhizosphere media and leaves at the end of the experiment (Figure 3a). Media $\delta^{15} \mathrm{~N}$ of inoculated iNoN 50 and inoculated iNoN 100 were $3.1 \%$ and 3.6\% higher, respectively, than both the inoculated and uninoculated iN 100 treatments. Media $\delta^{15} \mathrm{~N}$ at harvest was correlated positively with plant $\mathrm{N}$ uptake $(p=0.001$, Figure S1a).

Inoculated iNoN 100 plants had significantly higher $\delta^{15} \mathrm{~N}$ in leaves at harvest $(2.55 \%, \pm 0.31)$ than the other treatments, with the exception of controls $(1.29 \% \pm 0.79)$. In addition, iNoN 100 plants had $1.97 \%$ o higher leaf $\delta^{15} \mathrm{~N}$ when inoculated with PGPR than when they were uninoculated (Figure $3 b$ ). Leaf $\delta^{15} \mathrm{~N}$ at harvest was also correlated positively with plant $\mathrm{N}$ uptake ( $p=0.002$, Figure S1b). 

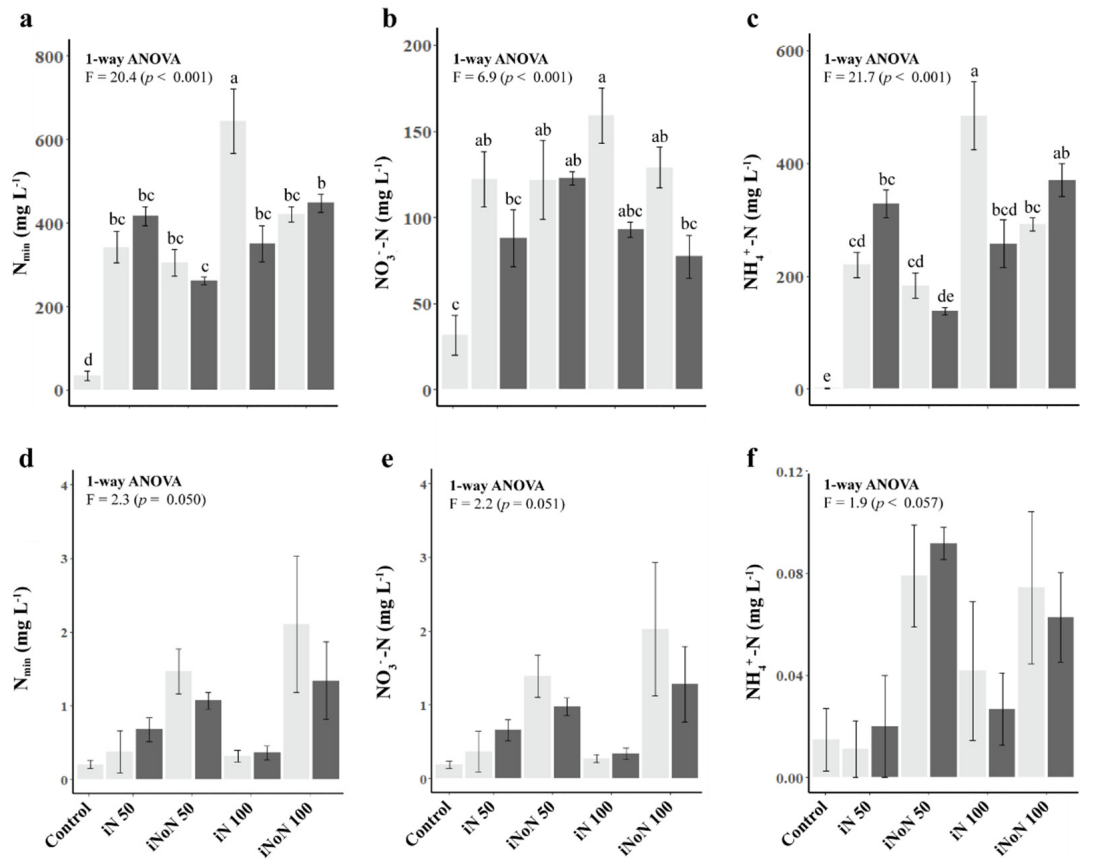

Figure 2. (a,d) Mineral $\mathrm{N}\left(\mathrm{N}_{\min }=\mathrm{NO}_{3}{ }^{-}-\mathrm{N}+\mathrm{NH}_{4}{ }^{+}-\mathrm{N},(\mathbf{b}, \mathbf{e})\right.$ nitrate $\left(\mathrm{NO}_{3}{ }^{-}-\mathrm{N}\right)$ and $(\mathbf{c}, \mathbf{f})$ ammonium $\left(\mathrm{NH}_{4}{ }^{+}-\mathrm{N}\right)$ concentrations in macadamia leachates after $(\mathbf{a}-\mathbf{c}) 3$ weeks and $(\mathbf{d}-\mathbf{f}) 11$ weeks growing under different fertilizer $\mathrm{N}$ sources (iN, iNoN) without or with PGPR inoculation. Light grey bars represent uninoculated treatments; dark grey bars display treatments inoculated with PGPR. Shown are mean mineral $\mathrm{N}$ concentrations in soil-leachate $( \pm \mathrm{SE}, n=4)$. Different letters above means indicate significant differences among treatments (one-way ANOVA and Tukey's post hoc tests, $p<0.05)$.

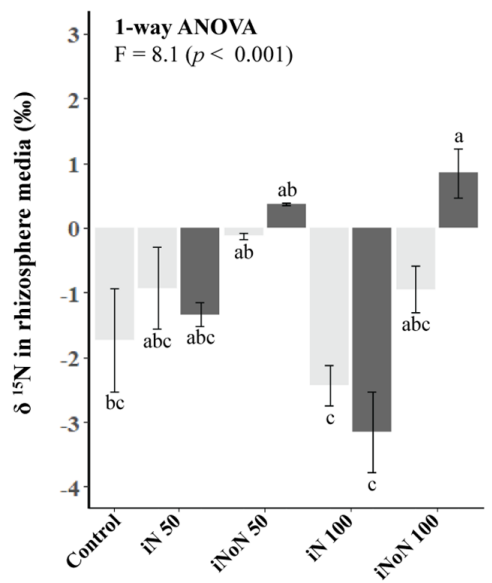

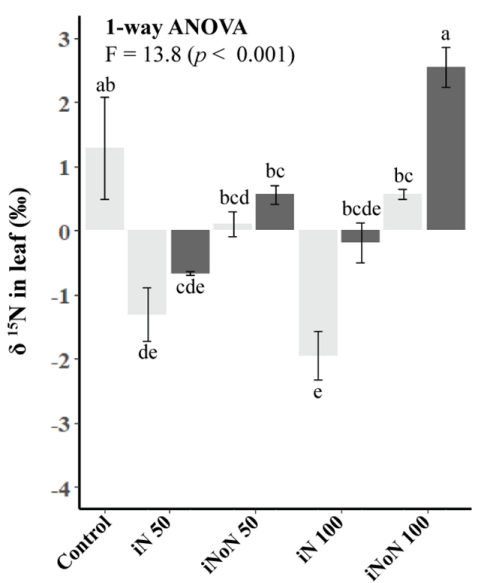

Figure 3. (a) Rhizosphere media $\delta^{15} \mathrm{~N}$ (\%) and (b) leaf $\delta^{15} \mathrm{~N}(\%$ ) in macadamia seedlings after 28 weeks growing under different fertilizer-N sources (iN, iNoN) without or with PGPR inoculation. Light grey bars represent uninoculated treatments; dark grey bars display treatments inoculated with PGPR. Shown are mean $\delta^{15} \mathrm{~N}$ values $( \pm \mathrm{SE}, n=3)$. Different lower-case letters above means indicate significant differences among treatments (1-way ANOVA and Tukey's post hoc tests, $p<0.05$ ).

\subsection{Microbial Responses}

The number of $16 \mathrm{~S}$ rRNA copies in the rhizosphere was, on average, $47 \%$ higher after 28 weeks than after 12 weeks (Figure $4 \mathrm{a}$ ). The number of $16 \mathrm{~S}$ copies did not differ significantly among treatments. The number of PGPR copies in the rhizosphere of inoculated trees in the iN 50, iNoN 50 and iNoN 100 treatments increased at least seven-fold 
by 28 weeks compared to that at 12 weeks (Figure $4 \mathrm{~b}$ ). In contrast, the number of PGPR copies in inoculated trees under the iN 100 treatment after 12 weeks was below the limit of detection, while after 28 weeks, PGPR copies were at least two-fold lower than the other inoculated treatments.
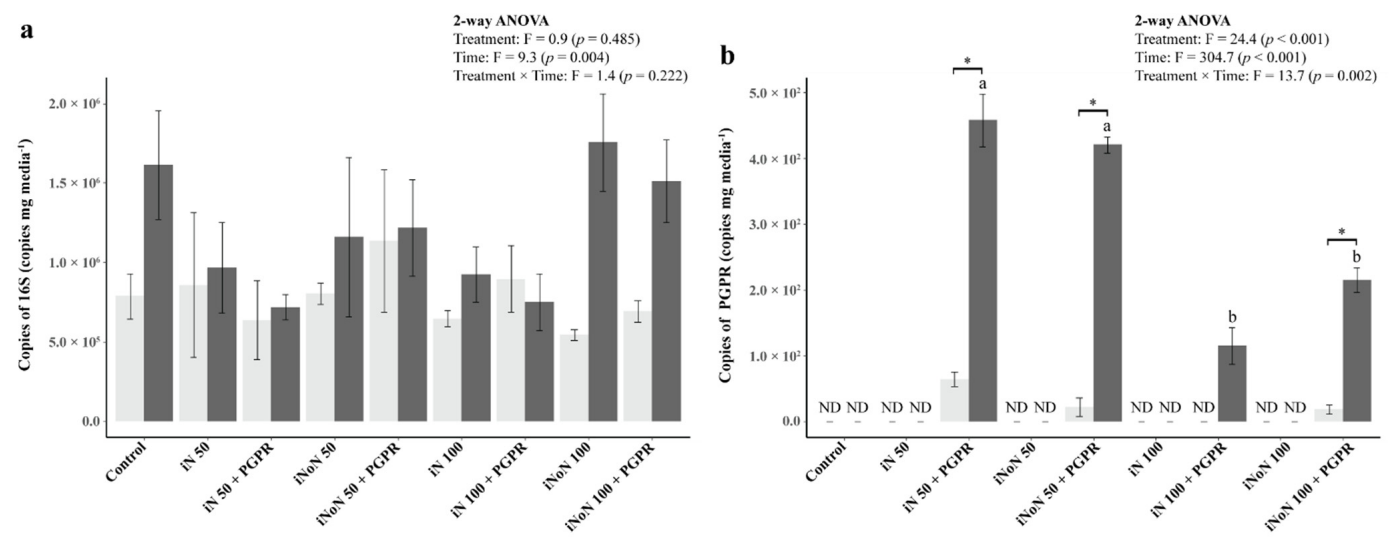

Figure 4. Copy numbers of the (a) 16S rRNA gene and (b) PGPR strain-specific gene PB_SOS3_004375 from rhizosphere potting mix of macadamia seedlings after 12 weeks (light grey bars) and 28 weeks (dark grey bars) growing under different fertilizer-N sources (iN, iNoN) without or with PGPR inoculation. Shown are the total number of gene copies per mg of soil $( \pm \mathrm{SE}, n=3)$. Asterisks and parentheses in panel $(\mathbf{b})$ indicate significant differences between time points within treatments (one-way ANOVA, $p<0.05$ ), while different lowercase letters above means indicate significant differences among treatments within a time point (one-way ANOVA and Tukey's post hoc test, $p<0.05$ ). ND: number of copies below limit of detection.

Rhizosphere microbial-biomass $\mathrm{N}$ differed among treatments after 12 weeks and 28 weeks (Figure 5), although no differences within $\mathrm{N}$ treatments were due to PGPR inoculation. Microbial-biomass $\mathrm{N}$ levels after 12 weeks were 4.5-fold higher in uninoculated iNoN 100 trees than in inoculated iN 50 and iN 100 trees (Figure 5a). Differences intensified over time, with microbial-biomass $\mathrm{N}$ increased up to 10-fold after 28 weeks in inoculated iNoN 100 trees when compared with the other treatments without or with PGPR, with the exception of iNoN 100 trees without PGPR (Figure 5b).
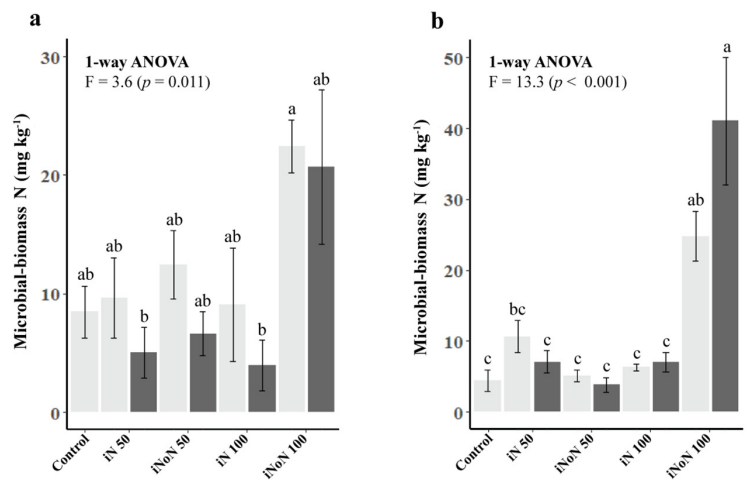

Figure 5. Microbial-biomass $\mathrm{N}\left(\mathrm{mg} \mathrm{kg}^{-1}\right)$ from rhizosphere potting mix of macadamia seedlings after (a) 12 weeks and (b) 28 weeks growing under different fertilizer-N sources (iN, iNoN) without or with PGPR inoculation. Light grey bars represent treatments not inoculated with PGPR; dark grey bars display treatments inoculated with PGPR. Shown are mean microbial-biomass $\mathrm{N}( \pm \mathrm{SE}, n=4)$. Different letters above means indicate significant differences among treatments (one-way ANOVA and Tukey's post hoc tests, $p<0.05)$.

\section{Discussion}

Root inoculation with PGPR has become recognized increasingly as an effective strategy to stimulate plant growth while reducing fertilizer inputs that damage terrestrial and aquatic ecosystems. We used a recently isolated PGPR from the genus Paraburkholderia 
that increases growth of kikuyu grass [31] to test whether $\mathrm{N}$ form and $\mathrm{N}$ level impact PGPR effects on growth, mineral $\mathrm{N}$ loss and plant $\mathrm{N}$ availability in a horticultural tree crop. We found that PGPR promoted growth of macadamia seedlings that were fertilized with urea and poultry manure at high $\mathrm{N}$ level (iNoN 100, $6 \mathrm{~g} \mathrm{~N}$ pot $^{-1}$ ) but not growth of seedlings that were fertilized with inorganic $\mathrm{N}$ alone (iN 50, iN 100). PGPR enhanced plant $\mathrm{N}$ acquisition and assimilation in the iNoN 100 treatment, which indicates that $\mathrm{N}$ fertilization directly impacts PGPR effects on mineral nutrient acquisition, biomass production and nutrient allocation. The synergistic effect observed after the co-application of PGPR and combined $\mathrm{N}$ forms is consistent with previous findings that show positive effects of PGPR in growth and nutrient acquisition [31]. Furthermore, recent studies have reported beneficial effects of other Paraburkholderia strains on plant growth in the field [39] and under controlled conditions $[40,41]$. In addition, our results provide further evidence that PGPR require an $\mathrm{N}$ level threshold to operate effectively [31,42]. These findings highlight that PGPR effects on $\mathrm{N}$ acquisition are more pronounced under a combination of inorganic and organic $\mathrm{N}$ forms, presumably due to greater soil quality and successive microbial $\mathrm{N}$ transformations. Our results extend previous investigations on the mechanisms behind PGPR growth promotion and underline the potential to directly impact plant $\mathrm{N}$ availability via $\mathrm{N}$ fixation, $\mathrm{N}-$ loss reduction and increased root surface area.

Strong development of root systems in planted seedlings is crucial for tree establishment and field performance after outplanting [43]. Nursery management practices often include inoculation with bacterial and fungal strains that improve root growth and consequently boost seedling health. The detection of PGPR in rhizosphere media samples from macadamia seedlings after 12 weeks confirmed that inoculation enabled PGPR to successfully colonize the rhizosphere. PGPR colonization increased over time, although abundance of the PGPR strain-specific gene compared with the 16S rRNA gene was low (relative abundance $<0.1 \%$ ). However, the relationship between microbial abundance and function in the rhizosphere is unclear. Recent studies suggest that low-abundance bacterial species may be the major drivers of microbiome function, given their role in protection against pathogens and biogeochemical cycles [44]. At least two mechanisms behind PGPR-driven beneficial effects on nutrient acquisition have been described; viz. the direct increase of nutrient supply in the rhizosphere, and the indirect stimulation of root ion transport systems [45]. Furthermore, plant growth promotion by PGPR is also associated with changes in concentration, localization and signaling of plant hormones [46]. Our results indicate that macadamia trees fertilized with the $\mathrm{N}$ treatment in which PGPR significantly enhanced growth (i.e., iNoN 100) also had an increase in the absorptive fineroot surface area, as found in chickpea [47]. PGPRs are able to produce indole-3-acetic acid (IAA) or are able to indirectly stimulate the plant auxin pathway, increase the number or length of lateral roots [48], and stimulate root hair elongation in vitro [49] to facilitate root colonization. Paraburkholderia spp. can modify root system architecture through the production of IAA [50]. The increase in surface area of the root system improves the plant's capacity to intercept water and nutrients and provides physical support to establish associative interactions with microbes and fungi. PGPR might intervene in the coordination between root development and nutrition via stimulation of ion transport systems or increased access to plant-available nutrients.

The plasticity of root traits enables plants to acclimate rapidly to nutrient changes and biotic or abiotic stresses. Plants encounter a range of organic and inorganic $\mathrm{N}$ compounds that can be taken up, and biomass allocation depends on soil $\mathrm{N}$ availability and $\mathrm{N}$ chemical composition [51,52]. The overall greater root partitioning observed in the control and inorganic $\mathrm{N}$ treatments than in the combined inorganic and organic $\mathrm{N}$ treatments suggests nutrient deficiency. In addition, the similar total biomass under low and high inorganic $\mathrm{N}$ treatments suggests an initial growth-suppressing effect of high mineral-N concentration in media. The iN 100 treatment likely caused an initially high soil $\mathrm{NH}_{4}{ }^{+}$ concentration, causing toxicity to the roots and growth inhibition [53]. A few weeks later, the plants overcame the growth inhibition when most $\mathrm{NH}_{4}{ }^{+}$was converted into $\mathrm{NO}_{3}{ }^{-}$ 
or lost. The resulting root phenotype after the co-application of inorganic and organic $\mathrm{N}$ forms has implications for sustainable agriculture. In the face of longer and more intensive drought periods, stimulation of drought-tolerant root traits might reduce mortality during field establishment.

We demonstrated that a two-fold increase in $\mathrm{N}$ addition leads to a $48 \%$ increase in mineral $\mathrm{N}$ leaching in the inorganic $\mathrm{N}$ treatment, but only a $27 \%$ increase when inorganic $\mathrm{N}$ is combined with manure. PGPR inoculation triggered a significant reduction in $\mathrm{NH}_{4}{ }^{+}-\mathrm{N}$ loss but this was only observed in the iN 100 treatment, in which the reduction in N loss did not translate into a growth increase. Moreover, our results suggest that the $\mathrm{N}$ form alone contributed to the reduction in $\mathrm{N}$ loss. Nitrogen pollution in ecosystems is generally due to the high mobility of $\mathrm{NO}_{3}{ }^{-}-\mathrm{N}$, but $\mathrm{NH}_{4}{ }^{+}-\mathrm{N}$ can also run off into waterways after heavy rain. Urea hydrolyzes into $\mathrm{NH}_{4}{ }^{+}$within a few days, stimulating the growth and activity of soil nitrifiers, which increase soil $\mathrm{NO}_{3}{ }^{-}$by nitrification of urea-derived $\mathrm{NH}_{4}{ }^{+}$. The quantitative analysis of nitrogen acquired by the trees relative to the $\mathrm{N}$ added and media $\mathrm{N}$ retained suggests that even treatments with high yield have substantial $\mathrm{N}$ loss. Factors such as duration of the experiment and growing conditions may have compromised the ability to observe significant differences in $\mathrm{N}$ use efficiency from PGPR-inoculation. Considering that containerized plants growing under frequent irrigation are exposed to significant denitrification and $\mathrm{N}$ leaching [4], further studies are required under field conditions. In our study, mineral $\mathrm{N}$ concentration in the leachates dropped dramatically by 11 weeks, although the trees continued growing. Therefore, our study suggests that internal sinks for mobilized $\mathrm{N}$, such as uptake by microbial biomass, and organically bound $\mathrm{N}$ in soil particles, created an effective buffer against $\mathrm{N}$ loss.

Organically amended soils, in contrast to conventionally managed systems, maintain steady $\mathrm{N}$ release, microbial diversity and structure of soil communities due to organically bound $\mathrm{N}[54,55]$. Nonetheless, some organic amendments (e.g., liquid manures) are prone to leaching, sometimes to a greater extent than high inorganic $\mathrm{N}$ rates [55]. The co-application of inorganic and organic $\mathrm{N}$ substrates promotes soil biological fertility by providing resources and habitats to stimulate microbial biomass and activity. Recent studies provide evidence that the addition of manure to mineral $\mathrm{N}$ fertilizers reduces $\mathrm{N}$ leaching and increases denitrifier activity [13,56]. Moreover, microbial inoculants have shown promise in inhibiting nitrification and increasing denitrifying communities [57]. In line with this, the high content of microbial biomass-N in the iNoN 100 treatment indicates strong microbial activity in the presence of manure. However, the quantitative analysis of $16 S$ copies, using qPCR, showed similar abundance of the bacterial population (16S rRNA) among treatments. These apparently contrasting results could be explained by an increase in fungal population in the iNoN 100 treatment due to the higher C content of manure or inter-sample variability in $16 \mathrm{~S}$ rRNA copies among treatments. Further investigations of microbial abundance and diversity after the co-application of manure and inorganic fertilizers are required to confirm redistribution of the microbial populations.

We studied media and plant $\mathrm{N}$ isotope composition $\left({ }^{15} \mathrm{~N}\right.$ natural abundance) to reconstruct the trajectory of $\mathrm{N}$ transformations that control $\mathrm{N}$ availability. PGPR inoculation increased leaf $\delta^{15} \mathrm{~N}$ in trees grown under iNoN 100. Despite the fact that we did not measure $\delta^{15} \mathrm{~N}$ signature in the applied fertilizers, inorganic $\mathrm{N}$ fertilizers (including urea) have generally lower $\delta^{15} \mathrm{~N}$ than organic fertilizers (including manure) [58]. Organic fertilizers can cause increased ${ }^{15} \mathrm{~N}$ values in plant tissues, with higher ${ }^{15} \mathrm{~N}$ values in plant tissues resulting from the uptake of ${ }^{15} \mathrm{~N}$-enriched manure-derived $\mathrm{N}$. In addition, the increase in $\mathrm{N}$ acquisition in PGPR-inoculated plants was associated with an increase in plant $\delta^{15} \mathrm{~N}$, suggesting an increase in $\mathrm{N}$ availability. We hypothesize that PGPR could play a key role in two mechanisms affecting $\mathrm{N}$ availability. Firstly, PGPR might reduce nitrification via biological nitrification inhibition (BNI) or increase denitrification [57]. A large body of research reports positive relationships between vegetation $\delta^{15} \mathrm{~N}$ and $\mathrm{N}$ losses or land management $[59,60]$, based on the fact that bacteria discriminate against ${ }^{15} \mathrm{~N}$ uptake during nitrification [61]. In this study, the analysis of ${ }^{15} \mathrm{~N}$ was performed at the end of the 
experiment when leaching was very low, while differences in growth among treatments occurred after 11 weeks (data not shown). The increase in media $\delta{ }^{15} \mathrm{~N}$ suggests that new $\mathrm{N}$ entered the system: $\mathrm{N}$ that was also subject to loss. Secondly, PGPR could act as diazotroph bacteria involved in biological $\mathrm{N}_{2}$ fixation (BNF) that could impact the plant's $\mathrm{N}$ budget directly by providing $\mathrm{N}$ fixed from the atmosphere. Diazotrophic bacteria, including Burkholderia, were isolated from various plant crops [62,63]. Free-living $\mathrm{N}$-fixing bacteria as well as denitrifying bacteria are heterotrophs; therefore, $\mathrm{C}$ availability is an important factor limiting their activity. Diazotrophs can access $\mathrm{N}$ via $\mathrm{N}$ fixation or through the uptake of lowand high-molecular-weight $\mathrm{N}$ sources [64]. In most cases, the decrease in $\mathrm{N}$ availability favors $\mathrm{N}_{2}$ fixation, although, under $\mathrm{N}$-depleted conditions, $\mathrm{N}$ limits nitrogenase synthesis and $\mathrm{N}_{2}$ fixation. This hypothesis could explain why PGPR did not affect growth in low $\mathrm{N}$ level treatments. Nonetheless, the impact of $\mathrm{N}_{2}$-fixation by PGPR is still debated and is rarely considered the reason for plant growth stimulation (for review, see [65]). Here, the high $\delta^{15} \mathrm{~N}$ values in the iNoN 100 treatment when inoculated with PGPR suggest that the potential PGPR-induced effects on reducing $\mathrm{N}$ leaching might be less important than the impacts of BNF on plant $\mathrm{N}$ availability.

\section{Conclusions}

This study demonstrated that inoculation of PGPR in combination with both inorganic and organic $\mathrm{N}$ at a high $\mathrm{N}$ level significantly enhances aboveground and fine-root growth and increases $\mathrm{N}$ uptake in macadamia seedlings. Based on our results, we can formulate two primary hypotheses to explain the observed PGPR effect. Firstly, PGPR intervened in rhizosphere soil $\mathrm{N}$ transformations. Secondly, the beneficial effects of PGPR were stimulated by the presence of organic $\mathrm{N}$, likely due to changes in the $\mathrm{C}$ and $\mathrm{N}$ economy of macadamia plants and media. Subsequent investigations will test the effects of PGPR inoculation and $\mathrm{N}$ fertilization on yield and soil properties under long-term field conditions. Future research on the interactions between PGPR and indigenous rhizosphere communities will provide a better understanding of the ecology of PGPR functional groups with the goal of promoting nutrient use efficiency in agriculture.

Supplementary Materials: The following are available online at https:/ / www.mdpi.com/article/10 .3390/agronomy11061064/s1, Table S1: Potting medium physicochemical properties after 28 weeks, Figure S1: Correlation between plant $\mathrm{N}$ uptake of Macadamia integrifolia and media $\delta^{15} \mathrm{~N}$, and leaf $\delta^{15} \mathrm{~N}$.

Author Contributions: Conceptualization, M.G., C.P.-L. and S.J.T. Methodology, data collection and original data analysis, M.G. and A.G. Data presentation, writing, reviewing and editing M.G., C.P.-L., A.G. and S.J.T. All authors have read and agreed to the published version of the manuscript.

Funding: This research was funded by the Cooperative Research Centre Project Grant CRCPFIVE000015.

Institutional Review Board Statement: Not applicable.

Informed Consent Statement: Not applicable.

Acknowledgments: We thank Joel Nichols and Tracey McMahon for assistance with growing plants and sampling in the glasshouse; Santi Krisantini for microbial analyses; The University of the Sunshine Coast for glasshouse facilities; The University of Queensland for nutrient analysis; the DES Chemistry Centre for leachate analysis; the Griffith Stable Isotope Laboratory for isotope analyses; and Zhihong $\mathrm{Xu}$ for interpretation of isotope results.

Conflicts of Interest: The authors declare no conflict of interest.

\section{References}

1. Vitousek, P.M.; Aber, J.D.; Howarth, R.W.; Likens, G.E.; Matson, P.A.; Schindler, D.W.; Schlesinger, W.H.; Tilman, D.G. Technical report: Human alteration of the global nitrogen cycle: Sources and consequences. Ecol. Appl. 1997, 7, 737. [CrossRef]

2. Rockström, J.; Steffen, W.; Noone, K.; Persson, A.; Chapin, F.S.; Lambin, E.F.; Lenton, T.M.; Scheffer, M.; Folke, C.; Schellnhuber, H.J.; et al. A safe operating space for humanity. Nat. Cell Biol. 2009, 461, 472-475. [CrossRef] 
3. Gruber, N.; Galloway, J.N. An Earth-system perspective of the global nitrogen cycle. Nat. Cell Biol. 2008, 451, 293-296. [CrossRef]

4. Majsztrik, J.C.; Fernandez, R.T.; Fisher, P.R.; Hitchcock, D.R.; Lea-Cox, J.; Owen, J.S.; Oki, L.R.; White, S.A. Water use and treatment in container-grown specialty crop production: A review. Water Air Soil Pollut. 2017, 228, 1-27. [CrossRef]

5. Tilman, D.; Cassman, K.G.; Matson, P.A.; Naylor, R.L.; Polasky, S. Agricultural sustainability and intensive production practices. Nat. Cell Biol. 2002, 418, 671-677. [CrossRef]

6. Bolan, N.; Szogi, A.; Chuasavathi, T.; Seshadri, B.; Rothrock, M.J.; Panneerselvam, P. Uses and management of poultry litter. Worlds Poult. Sci. J. 2010, 66, 673-698. [CrossRef]

7. Kumar, A.; Maiti, S.K. Effect of organic manures on the growth of Cymbopogon citratus and Chrysopogon zizanioides for the Phytoremediation of chromite-asbestos mine waste: A pot scale experiment. Int. J. Phytoremediat. 2014, 17, 437-447. [CrossRef]

8. Manlay, R.J.; Feller, C.; Swift, M. Historical evolution of soil organic matter concepts and their relationships with the fertility and sustainability of cropping systems. Agric. Ecosyst. Environ. 2007, 119, 217-233. [CrossRef]

9. Gutser, R.; Ebertseder, T.; Weber, A.; Schraml, M.; Schmidhalter, U. Short-term and residual availability of nitrogen after long-term application of organic fertilizers on arable land. J. Plant Nutr. Soil Sci. 2005, 168, 439-446. [CrossRef]

10. Sørensen, P.; Amato, M. Remineralisation and residual effects of $\mathrm{N}$ after application of pig slurry to soil. Eur. J. Agron. 2002, 16, 81-95. [CrossRef]

11. Schimel, J.P.; Bennett, J. Nitrogen mineralization: Challenges of a changing paradigm. Ecology 2004, 85, 591-602. [CrossRef]

12. Rees, R.; Castle, K. Nitrogen recovery in soils amended with organic manures combined with inorganic fertilisers. Agronomy 2002, 22, 739-746. [CrossRef]

13. Wen, Z.; Shen, J.; Blackwell, M.; Li, H.; Zhao, B.; Yuan, H. Combined applications of nitrogen and phosphorus fertilizers with manure increase maize yield and nutrient uptake via stimulating root growth in a long-term experiment. Pedosphere 2016, 26, 62-73. [CrossRef]

14. Zhong, W.; Gu, T.; Wang, W.; Zhang, B.; Lin, X.; Huang, Q.; Shen, W. The effects of mineral fertilizer and organic manure on soil microbial community and diversity. Plant Soil 2009, 326, 511-522. [CrossRef]

15. Francioli, D.; Schulz, E.; Lentendu, G.; Wubet, T.; Buscot, F.; Reitz, T. Mineral vs. organic amendments: Microbial community structure, activity and abundance of agriculturally relevant microbes are driven by long-term fertilization strategies. Front. Microbiol. 2016, 7, 1446. [CrossRef]

16. Denk, T.R.; Mohn, J.; Decock, C.; Lewicka-Szczebak, D.; Harris, E.; Butterbach-Bahl, K.; Kiese, R.; Wolf, B. The nitrogen cycle: A review of isotope effects and isotope modeling approaches. Soil Biol. Biochem. 2017, 105, 121-137. [CrossRef]

17. Gardner, J.B.; Drinkwater, L.E. The fate of nitrogen in grain cropping systems: A meta-analysis of $15 \mathrm{~N}$ field experiments. Ecol. Appl. 2009, 19, 2167-2184. [CrossRef] [PubMed]

18. Chalk, P.M.; Inácio, C.T.; Chen, D. An overview of contemporary advances in the usage of ${ }^{15} \mathrm{~N}$ natural abundance $\left(\delta^{15} \mathrm{~N}\right)$ as a tracer of agro-ecosystem N cycle processes that impact the environment. Agric. Ecosyst. Environ. 2019, 283, 106570. [CrossRef]

19. Trivedi, P.; Leach, J.E.; Tringe, S.G.; Sa, T.; Singh, B.K. Plant-microbiome interactions: From community assembly to plant health. Nat. Rev. Genet. 2020, 18, 1-15. [CrossRef] [PubMed]

20. Lareen, A.; Burton, F.; Schäfer, P. Plant root-microbe communication in shaping root microbiomes. Plant Mol. Biol. 2016, 90, 575-587. [CrossRef] [PubMed]

21. Berg, G.; Grube, M.; Schloter, M.; Smalla, K. Unraveling the plant microbiome: Looking back and future perspectives. Front. Microbiol. 2014, 5, 148. [CrossRef]

22. Zhang, R.; Vivanco, J.M.; Shen, Q. The unseen rhizosphere root-soil-microbe interactions for crop production. Curr. Opin. Microbiol. 2017, 37, 8-14. [CrossRef]

23. Bulgarelli, D.; Schlaeppi, K.; Spaepen, S.; Van Themaat, E.V.L.; Schulze-Lefert, P. Structure and functions of the bacterial microbiota of plants. Annu. Rev. Plant Biol. 2013, 64, 807-838. [CrossRef]

24. Mano, H.; Morisaki, H. Endophytic bacteria in the rice plant. Microbes Environ. 2009, 24, 193. [CrossRef]

25. Yang, J.; Kloepper, J.W.; Ryu, C.-M. Rhizosphere bacteria help plants tolerate abiotic stress. Trends Plant Sci. 2009, 14, 1-4. [CrossRef]

26. Van Loon, L.C.; Bakker, P.A.H.M.; Pieterse, C.M.J. Systemic resistance induced by rhizosphere bacteria. Annu. Rev. Phytopathol. 1998, 36, 453-483. [CrossRef]

27. Vessey, J.K. Plant growth promoting rhizobacteria as biofertilizers. Plant Soil 2003, 255, 571-586. [CrossRef]

28. Bashan, Y.; De-Bashan, L.E.; Prabhu, S.R.; Hernandez, J. Advances in plant growth-promoting bacterial inoculant technology: Formulations and practical perspectives (1998-2013). Plant Soil 2013, 378, 1-33. [CrossRef]

29. Yadav, R.; Suman, A.; Prasad, S.; Prakash, O. Effect of Gluconacetobacter diazotrophicus and Trichoderma viride on soil health, yield and N-economy of sugarcane cultivation under subtropical climatic conditions of India. Eur. J. Agron. 2009, 30, $296-303$. [CrossRef]

30. Riveracruz, M.; Trujillonarcia, A.; Cordovaballona, G.; Kohler, J.; Caravaca, F.; Roldan, A. Poultry manure and banana waste are effective biofertilizer carriers for promoting plant growth and soil sustainability in banana crops. Soil Biol. Biochem. 2008, 40, 3092-3095. [CrossRef]

31. Paungfoo-Lonhienne, C.; Redding, M.; Pratt, C.; Wang, W. Plant growth promoting rhizobacteria increase the efficiency of fertilisers while reducing nitrogen loss. J. Environ. Manag. 2019, 233, 337-341. [CrossRef] 
32. Paungfoo-Lonhienne, C.; Watanarojanaporn, N.; Jaemsaeng, R. Plant growth promoting rhizobacteria enhance the efficiency of the combination of organic and chemical fertilisers in sugarcane. Open J. Ecol. 2020, 10, 440-444. [CrossRef]

33. Rayment, G.E.; Lyons, D.J. Soil Chemical Methods-Australasia; CSIRO Publishing: Collingwood, VIC, Australia, 2010; ISBN 9780643101364.

34. Miller, R.O.; Kissel, D.E. Comparison of soil pH methods on soils of North America. Soil Sci. Soc. Am. J. 2010, 74, 310-316. [CrossRef]

35. Munter, R.; Grande, R. Plant tissue and soil extract analysis by ICP_Atomic emission spectrometry. In Developments in Atomic Plasma Spectrochemical Analysis; Heyden: London, UK, 1981; pp. 653-672.

36. Martinie, G.D.; Schilt, A.A. Wet oxidation efficiencies of perchloric acid mixtures for various organic substances and the identities of residual matter. Anal. Chem. 1976, 48, 70-74. [CrossRef]

37. Amato, M. Assay for microbial biomass based on ninhydrin-reactive nitrogen in extracts of fumigated soils. Soil Biol. Biochem. 1988, 20, 107-114. [CrossRef]

38. RStudio Team RStudio: Integrated Development for RStudio; PBC: Boston, MA, USA, 2020; Available online: http//www.rstudio.com (accessed on 25 May 2020).

39. Rahman, M.; Sabir, A.A.; Mukta, J.A.; Alam Khan, M.; Mohi-Ud-Din, M.; Miah, G.; Rahman, M.; Islam, M.T. Plant probiotic bacteria Bacillus and Paraburkholderia improve growth, yield and content of antioxidants in strawberry fruit. Sci. Rep. 2018, 8, 1-11. [CrossRef]

40. Poupin, M.J.; Timmermann, T.; Vega, A.; Zuñiga, A.; González, B. Effects of the plant growth-promoting bacterium Burkholderia phytofirmans PsJN throughout the life cycle of Arabidopsis thaliana. PLoS ONE 2013, 8, e69435. [CrossRef]

41. Puri, A.; Padda, K.P.; Chanway, C.P. Sustaining the growth of Pinaceae trees under nutrient-limited edaphic conditions via plant-beneficial bacteria. PLOS ONE 2020, 15, e0238055. [CrossRef]

42. Paungfoo-Lonhienne, C.; Lonhienne, T.G.A.; Yeoh, Y.K.; Donose, B.C.; Webb, R.I.; Parsons, J.; Liao, W.; Sagulenko, E.; Lakshmanan, P.; Hugenholtz, P.; et al. Crosstalk between sugarcane and a plant-growth promoting Burkholderia species. Sci. Rep. 2016, 6, 37389. [CrossRef]

43. Ritchie, G.A.; Tanaka, Y.; Meade, R.; Duke, S.D. Field survival and early height growth of Douglas-fir rooted cuttings: Relationship to stem diameter and root system quality. For. Ecol. Manag. 1993, 60, 237-256. [CrossRef]

44. Jousset, A.; Bienhold, C.; Chatzinotas, A.; Gallien, L.; Gobet, A.; Kurm, V.; Küsel, K.; Rillig, M.C.; Rivett, D.; Salles, J.F.; et al. Where less may be more: How the rare biosphere pulls ecosystems strings. ISME J. 2017, 11, 853-862. [CrossRef] [PubMed]

45. Vacheron, J.; Desbrosses, G.; Bouffaud, M.-L.; Touraine, B.; Moënne-Loccoz, Y.; Muller, D.; Legendre, L.; Wisniewski-Dyé, F.; Prigent-Combaret, C. Plant growth-promoting rhizobacteria and root system functioning. Front. Plant Sci. 2013, 4, 356. [CrossRef] [PubMed]

46. Tsukanova, K.; Chebotar, V.; Meyer, J.; Bibikova, T. Effect of plant growth-promoting Rhizobacteria on plant hormone homeostasis. S. Afr. J. Bot. 2017, 113, 91-102. [CrossRef]

47. Khan, N.; Bano, A.; Zandi, P. Effects of exogenously applied plant growth regulators in combination with PGPR on the physiology and root growth of chickpea (Cicer arietinum) and their role in drought tolerance. J. Plant Interact. 2018, 13, 239-247. [CrossRef]

48. Chamam, A.; Sanguin, H.; Bellvert, F.; Meiffren, G.; Comte, G.; Wisniewski-Dyé, F.; Bertrand, C.; Prigent-Combaret, C. Plant secondary metabolite profiling evidences strain-dependent effect in the Azospirillum-Oryza sativa association. Phytochemistry 2013, 87, 65-77. [CrossRef] [PubMed]

49. Contesto, C.; Desbrosses, G.; Lefoulon, C.; Béna, G.; Borel, F.; Galland, M.; Gamet, L.; Varoquaux, F.; Touraine, B. Effects of rhizobacterial ACC deaminase activity on Arabidopsis indicate that ethylene mediates local root responses to plant growthpromoting rhizobacteria. Plant Sci. 2008, 175, 178-189. [CrossRef]

50. Zúñiga, A.; Poupin, M.J.; Donoso, R.; Ledger, T.; Guiliani, N.; Gutiérrez, R.A.; González, B. Quorum sensing and indole-3-acetic acid degradation play a role in colonization and plant growth promotion of Arabidopsis thaliana by Burkholderia phytofirmans PsJN. Mol. Plant Microbe Interact. 2013, 26, 546-553. [CrossRef] [PubMed]

51. Hermans, C.; Hammond, J.P.; White, P.J.; Verbruggen, N. How do plants respond to nutrient shortage by biomass allocation? Trends Plant Sci. 2006, 11, 610-617. [CrossRef]

52. Cambui, C.A.; Svennerstam, H.; Gruffman, L.; Nordin, A.; Ganeteg, U.; Näsholm, T. Patterns of plant biomass partitioning depend on nitrogen source. PLoS ONE 2011, 6, e19211. [CrossRef]

53. Britto, D.T.; Kronzucker, H. $\mathrm{NH}_{4}{ }^{+}$toxicity in higher plants: A critical review. J. Plant Physiol. 2002, 159, 567-584. [CrossRef]

54. Lori, M.; Symanczik, S.; Mäder, P.; Efosa, N.; Jaenicke, S.; Buegger, F.; Tresch, S.; Goesmann, A.; Gattinger, A. Distinct nitrogen provisioning from organic amendments in soil as influenced by farming system and water regime. Front. Environ. Sci. 2018, 6. [CrossRef]

55. Edmeades, D.C. The long-term effects of manures and fertilisers on soil productivity and quality: A review. Nutr. Cycl. Agroecosyst. 2003, 66, 165-180. [CrossRef]

56. Kramer, S.B.; Reganold, J.P.; Glover, J.D.; Bohannan, B.J.M.; Mooney, H.A. Reduced nitrate leaching and enhanced denitrifier activity and efficiency in organically fertilized soils. Proc. Natl. Acad. Sci. USA 2006, 103, 4522-4527. [CrossRef]

57. Florio, A.; Pommier, T.; Gervaix, J.; Bérard, A.; Le Roux, X. Soil C and N statuses determine the effect of maize inoculation by plant growth-promoting rhizobacteria on nitrifying and denitrifying communities. Sci. Rep. 2017, 7, 1-12. [CrossRef] [PubMed] 
58. Szpak, P.; Longstaffe, F.J.; Millaire, J.-F.; White, C.D. Stable isotope biogeochemistry of seabird guano fertilization: Results from growth chamber studies with maize (Zea mays). PLoS ONE 2012, 7, e33741. [CrossRef]

59. Karwat, H.; Egenolf, K.; Nuñez, J.; Rao, I.; Rasche, F.; Arango, J.; Moreta, D.; Arevalo, A.; Cadisch, G. Low ${ }^{15} \mathrm{~N}$ natural abundance in shoot tissue of Brachiaria humidicola is an indicator of reduced $\mathrm{N}$ losses due to Biological Nitrification Inhibition (BNI). Front. Microbiol. 2018, 9, 2383. [CrossRef]

60. Pardo, L.H.; Hemond, H.F.; Montoya, J.P.; Fahey, T.J.; Siccama, T.G. Response of the natural abundance of ${ }^{15} \mathrm{~N}$ in forest soils and foliage to high nitrate loss following clear-cutting. Can. J. For. Res. 2002, 32, 1126-1136. [CrossRef]

61. Högberg, P. Tansley Review No. $95^{15} \mathrm{~N}$ natural abundance in soil-plant systems. New Phytol. 1997, 137, 179-203. [CrossRef]

62. Perin, L.; Martinez-Aguilar, L.; Castro-Gonzalez, R.; Santos, P.E.-D.L.; Cabellos-Avelar, T.; Guedes, H.V.; Reis, V.M.; CaballeroMellado, J. Diazotrophic Burkholderia species associated with field-grown maize and sugarcane. Appl. Environ. Microbiol. 2006, 72, 3103-3110. [CrossRef]

63. Castro-González, R.; Martínez-Aguilar, L.; Ramírez-Trujillo, A.; Santos, P.E.-D.L.; Caballero-Mellado, J. High diversity of culturable Burkholderia species associated with sugarcane. Plant. Soil 2011, 345, 155-169. [CrossRef]

64. Reed, S.C.; Cleveland, C.C.; Townsend, A.R. Functional ecology of free-living nitrogen fixation: A contemporary perspective. Annu. Rev. Ecol. Evol. Syst. 2011, 42, 489-512. [CrossRef]

65. Dobbelaere, S.; Vanderleyden, J.; Okon, Y. Plant growth-promoting effects of diazotrophs in the rhizosphere. Crit. Rev. Plant. Sci. 2003, 22, 107-149. [CrossRef] 